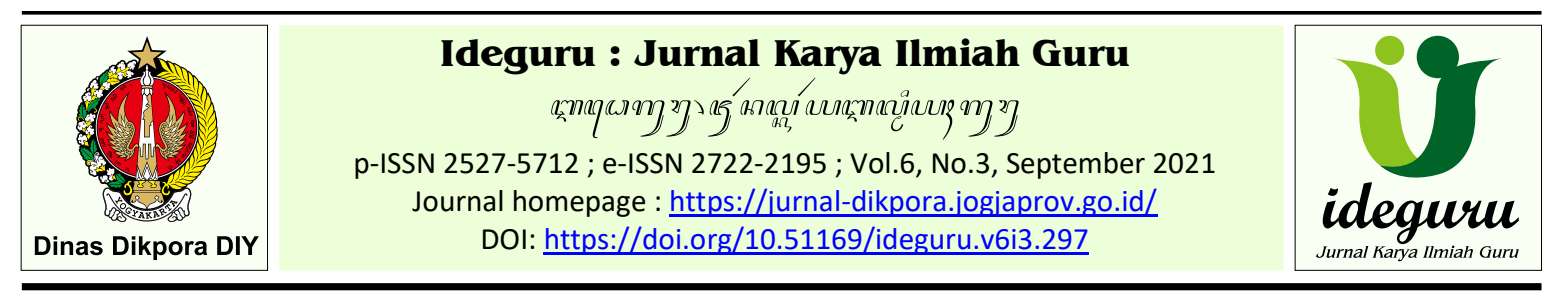

Artikel Penelitian - Naskah dikirim: 14/06/2021 - Selesai revisi: 09/08/2021 - Disetujui: 12/08/2021 - Diterbitkan: 01/09/2021

\title{
Bimtek In-On-In Daring untuk Meningkatkan Kompetensi Guru Menyusun RPP PJJ Kelas Khusus Olahraga
}

\author{
Jaka Tumuruna \\ SMA Negeri 4 Yogyakarta \\ tumurunajaka@yahoo.co.id
}

\begin{abstract}
Abstrak: Penelitian Tindakan Sekolah ini bertujuan untuk mengetahui tingkat keberhasilan kegiatan bimbingan teknis In-On-In daring dalam rangka meningkatkan kemampuan guru kelas khusus olahraga dalam membuat RPP pada masa pandemi covid-19 yang berorientasi pada siswa. Dalam penelitian ini menggunakan metode penelitian tindakan sekolah. Subjek penelitian ini terdiri dari guru muda dan senior yang mengajar di kelas khusus olahraga yang berjumlah 17 (tujuh belas) orang. Penelitian ini dilakukan selama 2 (dua) bulan dengan dua kali siklus, masing-masing siklus dilakukan lima kali pertemuan. Setiap siklus terdiri dari perencanaan, pelaksanaan, pengamatan, dan refleksi. Hasil kegiatan bimbingan teknis penyusunan RPP PJJ daring dapat meningkatkan kemampuan guru kelas khusus olahraga dalam menyusun RPP PJJ merupakan indikator keberhasilan dalam penelitian ini. Tingkat keberhasilan dalam penelitian ini rata-rata siklus 1 mencapai 79,20 naik menjadi 84,98. Hasil penyusunan RPP PPJ ditriangulasikan dengan hasil observasi pembelajaran dan hasil angket siswa. Dari triangulasi data ini dapat disimpulkan bahwa hasil peningkatan kompetensi penyusunan RPP sejalan dengan kenaikan kualitas pembelajaran yang dirasakan oleh siswa. Perbandingan hasil rata-rata angket siswa pratindakan mencapai 77,44 kategori cukup, dan setelah siklus 2 mencapai 91 kategori amat baik.
\end{abstract}

Kata kunci: kompetensi guru, penyusunan RPP PJJ, bimtek in on in.

\section{Online In-On-In Technical Guidance to Improve Teachers Competence in Preparing Distance Learning Lesson Plans for Sports Special Class Teachers}

\begin{abstract}
This Classroom Action Research aims to determine the success rate of online In-On-In technical guidance to improve the ability of special sports class teachers in making student-oriented lesson plans during the COVID-19 pandemic. This study useS the classroom action research method. The subjects of this study consisted of young and senior teachers who taught in sports special classes totaling 17 (seventeen) people. This research was conducted for 2 (two) months with two cycles, each cycle carried out five meetings. Each cycle consists of planning, implementation, observation, and reflection. The indicator of success in this study is the improvement of the ability of special sports class teachers in compiling the Distance Learning Lesson Plans. The success rate in this study, the average of cycle 1 reached 79.20 points and rose to 84.98 points. The results of the preparation of Distance Learning Lesson Plans were triangulated with the results of learning observations and the results of student questionnaires. From the triangulation of this data, it can be concluded that the results of increasing competence in preparing lesson plans are in line with the increase in the quality of learning according to the student's testimony. The comparison of the average results of the pre-action student questionnaires reached 77.44 points (moderate categories), and after cycle 2 it reached 91 points (very good categories).
\end{abstract}

Keywords: teacher's competence, distance learning lesson plans making, in on in technical guidance.

\section{Pendahuluan}

SMA Negeri 4 Yogyakarta merupakan sekolah reguler yang mempunyai Kelas Khusus Olahraga (KKO). KKO merupakan model pelaksanaan pendidikan yang diaplikasikan agar kualitas pengetahuan, sikap dan keterampilan siswa yang mempunyai bakat olahraga tetap berkembang secara maksimal. KKO setiap jenjang terdiri satu kelas dengan masing-masing rombongan belajar berjumlah 36 (tiga puluh enam) pada tahun pelajaran 2020/2021. Selain berkewajiban mengikuti kegiatan akademik juga mengikuti pelatihan berbagai cabang olah raga. Sehingga siswa KKO memiliki dua kewajiban yaitu sebagai siswa yang harus mengikuti proses pembelajaran di kelas dan sebagai atlet yang harus mengikuti latihan praktik olahraga. 
Tujuan menyelenggarakan program KKO adalah untuk pembinaan dan pengembangan kemampuan siswa dalam bidang olahraga ditingkat sekolah menengah serta untuk mewadahi para siswa yang mempunyai bakat olahraga sesuai cabang olahraganya untuk berkesempatan belajar di SMA Negeri 4 Yogyakarta. Melalui pembinaan dan pengembangan tersebut, diharapkan terbentuk atlet-atlet yang berprestasi yang bisa mewakili daerah dan negara untuk berkompetisi dalam bidang olahraga.

Selama masa pandemi Covid-19, siswa kelas khusus olahraga memiliki dua kewajiban yaitu mengikuti proses belajar daring dan sebagai atlet yang harus mengikuti latihan praktik olahraga. Hasil dalam mengikuti pelajaran daring dapat diketahui dari nilai raport yang mencapai KKM. Data yang diperoleh pada semester satu tahun pelajaran 2020/2021 menunjukkan prestasi akademik siswa KKO belum seperti yang diharapkan. Siswa kelas X tuntas KKM ada 90.63 $\%$, belum tuntas 9,37\%, dan kelas XI tuntas KKM ada $95.93 \%$, belum tuntas ada $4.07 \%$.

Berdasarkan hasil angket, ketidaktuntasan KKM bersumber dari guru dan siswa. Beberapa masalah yang terjadi pada siswa KKO dimasa pandemi Covid-19 ini, diantaranya: 1) saat mengikuti PJJ motivasi belajar siswa rendah; 2) pengumpulan tugas tidak tepat waktu; 3) sering terlambat mengikuti KBM; 4) ketika mengerjakan tugas hanya menyontek; 5) siswa belum mumpuni dalam mengoperasikan aplikasi yang digunakan dalam PJJ; 6) siswa kurang aktif bertanya pada guru apabila ada materi yang belum dimengerti; 7) siswa lebih mementingkan latihan cabang olahraga yang dipilih daripada pelajaran; 8) siswa tidak memperhatikan materi yang diberikan guru.

Disamping permasalahan yang bersumber pada siswa, beberapa masalah yang terjadi pada guru, diantaranya: 1) guru tidak pernah mendapatkan bimbingan membuat RPP PJJ; 2) sebagian guru belum menyusun RPP PJJ sesuai karakter siswa KKO; 3) sekolah belum pernah melaksanakan bimtek penyusunan RPP PJJ bagi guru yang mengajar di kelas KKO, 4) sebagian guru hanya melakukan copi paste dari internet atau sekolah lain dalam membuat RPP sehingga sering tejadi ketidaksesuaian antara perencanaan dengan pelaksanaan.

Berdasarkan Permendikbud No.16 Tahun 2007, empat kompetensi yang harus dimiliki guru adalah yaitu: kompetensi pedagogik, kompetensi kepribadian, kompetensi sosial, dan kompetensi profesional. Kompetensi pedagogik yaitu kompetensi guru dalam membuat perencanakan, melaksanakan, dan mengevaluasi proses pembelajaran. Keberhasilan pelaksanaan pembelajaran dan evaluasi sangat ditentukan oleh baik tidaknya perencanaan pembelajaran sehingga setiap guru harus menyusun RPP. Trianto (Setiana, 2018: 121) mengemukakan RPP adalah pedoman guru dalam kegiatan pembelajaran yang disusun dalam skenario kegiatan. Guru yang mengajar di KKO harus mampu menyusun RPP PJJ sesuai dengan kondisi siswa yang dihadapi.

Kompetensi guru dalam penelitian tindakan sekolah ini adalah kemampuan 17 (tujuh belas) guru kelas khusus olahraga dalam membuat Rencana Pelaksanaan Pembelajaran (RPP) PJJ yang efektif, efisien dan berorientasi pada siswa. Berkaitan dengan program merdeka belajar, telah diterbitkan surat edaran Menteri No 4 Tahun 2019 tentang Penyederhaan Rencana Pelaksanaan Pembelajaran. Surat edaran ini menyebutkan bahwa penyusunan RPP harus memenuhi tiga prinsip, yaitu: Efektif berarti dapat membantu guru dalam mencapai tujuan pembelajaran, Efisien berarti tidak menghabiskan waktu dan tenaga dalam penyusunan maupun dalam pelaksanaan pembelajaran., Berorientasi pada siswa berarti menyesuaikan kesiapan, kebutuhan, dan ketertarikan siswa.

Selanjutnya dijelaskan dalam surat edaran tersebut bahwa RPP sederhana setidaknya mengandung tiga unsur, yaitu: tujuan pembelajaran, langkah-langkah pembelajaran, dan penilaian. Tujuan pembelajaran dirumuskan pada kurikulum dan kebutuhan belajar siswa. Langkah-langkah pembelajaran dan penilaian harus efisien dan efektif. Penilaian harus merujuk pada tujuan pmbelajaran, sehingga penilaian yang efektif dapat mengukur ketercapaian tujuan pembelajaran. Sedangkan komponen lain seperti materi pembelajaran dan instrument penilaian merupakan unsur pelengkapnya.

Solusi yang dapat dilakukan untuk meningkatkan kompetensi guru dalam menyusun RPP PJJ KKO adalah kegiatan bimtek dalam bentuk In-On-In daring. Dalam hal ini Bimtek In dilaksanakan melalui zoom cloud meeting. Sedangkan Bimtek On dilakukan melalui Whatsapp. Dipilih zoom cloud meeting untuk pertemuan In karena moda ini sudah dikenal oleh guru dan akses mudah. Sementara itu, untuk pertemuan On, Whatsapp digunakan sebagai alat bantu komunikasi karena moda ini sangat familier, mudah, dan murah

Menurut Natawidjaya (Tan \& Indrasti, 2018: 246), bimtek sama dengan pembelajaran informal dalam praktiknya peserta mendapatkan pembekalan ilmu pengetahuan dan mendapatkan 
pelatihan-pelatihan yang terkait dengan peningkatan kompetensi. Bimtek juga merupakan salah satu strategi pemberdayaan, karena dalam Bimtek diberikan materi yang berhubungan dengan upaya memecahkan masalah yang dihadapi di lapangan.

Bimtek In-On-In pada dasarnya adalah pelaksanaan bimbingan secara berkelanjutan yang dibagi menjadi tiga bagian utama: 1) In1, 2) On, dan 3) In2.

Pada pertemuan $\operatorname{In} 1$, kepala sekolah dibantu narasumber melakukan bimbingan kepada guru. Dalam hal ini, narasumber memberikan teori dan konsep penyusunan RPP PJJ, memberikan contoh, diskusi, memberikan tugas kepada guru untuk mengerjakan pada saat Bimtek, mencermati hasil pekerjaan, serta memberikan umpan balik.

Pada kegiatan On, guru mengerjakan tugas secara mandiri. Tugas yang diberikan narasumber tersebut dapat dikerjakan di rumah atau di sekolah dengan batasan waktu yang telah ditetapkan. Setelah selesai menyusun RPP secara mandiri, guru bekerjasama dengan teman sejawat untuk melakukan telaah RPP.

Pada pertemuan In2, guru menunjukkan hasil pekerjaannya kepada narasumber untuk dinilai/dipresentasikan sehingga dapat diketahui apakah hasil yang dicapai sudah sesuai dengan bimbingannya atau belum. Namun apabila hasilnya belum sesuai, narasumber melakukan bimbingan kembali secara berkelanjutan/pola InOn-In sampai hasilnya tercapai sesuai dengan harapan.

Bimtek In-On-In Penulis pilih karena memiliki keunggulan yaitu kegiatan dapat dilakukan tanpa mengganggu proses pembelajaran dan bimbingan kegiatan dapat lebih intensif.

Berdasarkan masalah yang terjadi maka tujuan dalam penelitian ini adalah 1) Meningkatkan kompetensi guru KKO dalam menyusun RPP PJJ melalui Bimtek In-On-In moda daring di SMA Negeri 4 Yogyakarta. 2) Mendiskripsikan langkah-langkah bimbingan teknis (Bimtek) In-On-In moda daring yang dapat meningkatkan kompetensi guru KKO di SMAN 4 Yogyakarta dalam menyusun RPP PJJ.

Manfaat yang diperoleh dalam penelitian ini antara lain: 1) Kepala sekolah dapat menemukan metode yang tepat untuk meningkatkan kompetensi guru dalam menyusun RPP. 2) Terjadi peningkatan kompetensi dan profesional kepala sekolah dalam melakukan peningkatan keprofesionalan guru.

\section{Metode Penelitian}

Penelitian dilakukan di SMA Negeri 4 Yogyakarta dari bulan Januari sampai dengan. April 2021. Subjek penelitian ini adalah guru yang mengajar di kelas khusus olahraga SMA Negeri 4 Yogyakarta yang berjumlah 17 (tujuh belas) orang yang terdiri guru muda dan senior.

Penelitian ini dilakukan dengan metode Penelitian Tindakan Sekolah dalam tahapan bersiklus. Penelitian ini mengacu pada model Kemmis dan Taggart (2000) yang mengembangkan suatu konsep dengan model spiral yang terdiri dari empat tahap: perencanaan (planning), pelaksanaan (acting), pengamatan (observing) dan merefleksi (reflection).

Penelitian dilakukan 2 (dua) siklus. Tahapan penelitian tindakan sebagai berikut. Pertama, perencanaan. Dalam tahap ini persiapan meliputi: (1) menjelaskan pada guru tentang tindakan yang akan dilakukan; (2) menetapkan 1 (satu) narasumber yang mempunyai pengalaman dalm penyusunan RPP PJJ dengan program Bimtek untuk guru KKO di SMA Negeri 4 Yogyakarta; (3) bersama kolaborator, peneliti memilih teknik pembimbingan yang akan dilakukan; dan (4) membuat kelengkapan administrasi antara lain catatan lapangan, lembar pengamatan, angket, dan lembar umpan balik guru, lembar penilaian setiap siklus. Kelengkapan administrasi disesuaikan dengan teknik pembimbingan yang ditentukan.

Kedua, pelaksanaan. Merupakan implementasi (pelaksanaan) dari semua rencana yang telah dibuat dan hasilnya diharapkan dapat meningkatkan kompetensi guru KKO dalam menyusun RPP PJJ. Kolaborator berperan membantu peneliti untuk dapat mempertajam refleksi dan evaluasi yang dilakukan.

Ketiga, Pengamatan. Kegiatan pengamatan dilakukan bersamaan dengan pelaksanaan tindakan. Data akan dikumpulkan pada tahap ini yang berisi tentang pelaksanaan tindakan dan rencana yang sudah dibuat, serta dampaknya terhadap proses tindakan. Penelitian ini bersifat kolaboratif dimana peneliti melibatkan seorang kolaborator, yaitu Drs Aris Priyanto, M.Or. pengawas sekolah dari balai pendidikan menengah kota Yogyakarta yang mempunyai kompetensi dalam bidang olahraga dan penelitian tindakan sekolah. Penelitian ini melibatkan kolaborator agar tidak terjadi penelitian tunggal yang berpotensi terjebak dalam subjektivitas. Sebagai konsekwensi atas sifat kolaboratif maka dalam setiap tahapan diperlukan koordinasi dan konsolidasi antara peneliti dan kolaborator sehingga dalam tahap 
pengamatan dilakukan bersama kolaborator sebagai observer.

Keempat, merefleksi. Dalam tahap refleksi ini, peneliti mengulas hasil pengamatan, melakukan evaluasi tindakan yang telah dilakukan meliputi evaluasi mutu, jumlah dan waktu dari setiap tindakan, evaluasi terhadap skenario.

Teknik pengumpulan data dalam penelitian ini yaitu: wawancara, observasi, dokumen, dan angket. Instrumen yang digunakan dalam pengumpulan data meliputi: pedoman wawancara, lembar observasi, dokumentasi, dan lembar angket.

Wawancara dilakukan kepada guru yang mengajar di kelas khusus olahraga terkait dengan permasalahan yang terjadi serta pada setiap akhir siklus tindakan untuk menggali informasi permasalahan atau kesulitan guru dalam menyusun RPP Pembelajaran Jarak Jauh (PJJ).

Observasi dilakukan dengan lembar observasi untuk mengamati keterlaksanaan Bimtek In-On-In secara daring bagi guru kelas khusus olahraga dalam menyusun RPP PJJ pada saat dilaksanakan bimbingan.

Dokumentasi digunakan untuk memperoleh data mengenai pelaksanaan Bimtek daring, tanggapan guru terhadap Bimtek PJJ daring, kemajuan guru dalam melaksanakan penyusunan RPP PJJ. Dokumentasi yang dilakukan dengan menggunakan foto dan rekaman video.

Angket digunakan untuk menilai kualitas RPP dan menggali persepsi guru terhadap Bimtek In-On-In tentang penyusunan RPP menggunakan skala 4.

Penelitian ini menggunakan analisis data kualitatif model mengalir dari Miles dan Huberman yang meliputi tiga hal yaitu: reduksi data, penyajian data, penarikan kesimpulan.

\section{Hasil dan Pembahasan}

Langkah-langkah bimtek In-On-In daring untuk meningkatkan kompetensi guru dalam menyusun RPP PJJ KKO di SMA Negeri 4 Yogyakarta terdiri dari 2 (dua) siklus. Masingmasing siklus terdiri dari kegiatan In1, On, dan In2.

Pada kegiatan siklus I, kegiatan In1 diisi dengan pemberian pemaparan materi tentang gaya belajar siswa. Pada kegiatan On, guru diminta membuat RPP PJJ yang efektif, efisien, dan berorientasi pada karakteristik dan gaya belajar siswa KKO. Pada kegiatan In2, guru mempresentasikan hasil penyusunan RPP PJJ KKO dan ditelaah serta diberikan umpan balik oleh Peneliti dan narasumber.
Pada kegiatan sikuls II, kegiatan In1 diisi dengan pemberian pemaparan materi tentang pengelolaan kelas daring dan model-model pembelajaran. Pada kegiatan On, guru diminta membuat RPP PJJ yang efektif, efisien, dan berorientasi pada karakteristik dan gaya belajar siswa KKO. Pada kegiatan In2, guru mempresentasikan hasil penyusunan RPP PJJ KKO dan ditelaah serta diberikan umpan balik oleh Peneliti dan narasumber.

Hasil pengamatan melalui zoom meeting pada peserta bimtek pertemuan pertama yaitu masih ada guru yang kurang antusias dalam mengikuti bimtek daring dan keterlibatan dalam tanya jawab di zoom masih kurang, namun pada pertemuan In 2 terjadi perubahan. Guru sudah mulai terbiasa dengan zoom meeting dan diskusi berjalan lancar. Pada kegiatan On yang berlangsung dua hari, percakapan guru berlangsung cukup baik. Beberapa guru beralasan kerepotan urusan keluarga sehingga belum menyelesaikan RPP dan belum melakukan telaah silang. Usaha kepala sekolah bersama narasumber dilakukan dengan terus menerus memotivasi sehingga 17 guru berhasil menyelesaikan RPP. Hasil pengamatan kolaborator pada kegiatan In 2 pada tahap presentasi RPP tercatat bahwa guru tumbuh motivasinya. Hal ini terlihat dari adanya kemauan guru mempresentasikan RPP dengan baik dan guru lain menanggapi. Diskusi yang dipandu oleh kepala sekolah dan narasumber menghasilkan RPP yang lebih baik.

Tabel 1. Hasil Telaah RPP Siklus 1

\begin{tabular}{|c|c|c|c|}
\hline \multirow{2}{*}{ No } & \multirow{2}{*}{ Nama } & \multicolumn{2}{|c|}{ Siklus 1} \\
\hline & & Nilai & Kategori \\
\hline & $\begin{array}{l}\text { Identitas dan kelengkapan } \\
\text { komponen }\end{array}$ & 88.24 & Baik \\
\hline 2. & Tujuan pembelajaran & 76.47 & Cukup \\
\hline 3. & Kegiatan pembelajaran & 79.99 & Cukup \\
\hline & n pembelajaran & 75.73 & Cukup \\
\hline & Lamp & 79.04 & Cukup \\
\hline & Rerata & 79.2 & Cukup \\
\hline
\end{tabular}

Berdasarkan tabel 1, hasil telaah RPP sejumlah 17 guru pada siklus 1 belum efektif, efisien, dan berorientasi pada siswa. Pada siklus I tujuan pembelajaran, kegiatan pembelajaran, penilaian pembelajaran, lampiran mempunyai nilai cukup belum mencapai nilai baik.

Terdapat kelemahaan-kelemahan yang perlu diperbaiki, antara lain: 1) tujuan pembelajaran sebagian belum mencantumkan ranah sikap; 2) langkah-langkah pembelajaran belum dituangkan secara sistematis masih menghabiskan banyak waktu dan tenaga; 3) metode dan model belum dicantumkan yang 
digunakan sehingga belum dapat membantu pencapaian tujuan; 4) belum semua penilaian keterampilan direncanakan secara baik; 5) platform daring yang dipergunakan belum tersurat pada RPP; 6) siswa kurang optimal dalam mengikuti proses pembelajaran karena materi yang disusun kurang; 7) media yang digunakan guru sulit dan belum bisa diakses oleh siswa sehingga siswa lama dalam bergabung dalam proses pembelajaran yang diberikan guru; 8)belum semua melampirkan materi yang bersifat esensial; 9)materi belum disusun dengan sistematis sehingga sulit dipelajari siswa; dan 10)pada penilaian belum semua mencantumkan penilaian sikap, keterampilan, dan pengetahuan.

Berdasarkan telaaah tersebut, disarankan agar guru: 1) melakukan penyusunan RPP yang efektif dan efisien; 2) memilih pendekatan dan metode yang sesuai dengan bagi anak; 3) menyusun materi pelajaran agar di susun secara sistematis; 4) mencantumkan pendekatan dan metode yang akan dilakukan dalam tujuan pembelajaran; 5) mencantumkan ranah kognitif, afektif dan psikomotor tujuan pembelajaran; 6) melampirkan materi yang bersifat esensial; dan 7) mencantumkan penilaian sikap, keterampilan, dan pengetahuan; 8) menyusun RPP menyesuaikan dengan pembelajaran jarak jauh, dan 9) disarankan untuk menyusun RPP sesuai dengan kondisi siswa.

Oberservasi pembelajaran dilakukan guru dan kepala terhadap guru yang ditunjuk untuk diobservasi dalam proses pembelajaran.

Tabel 2. Rata-rata Hasil Observasi pembelajaran Siklus 1

\begin{tabular}{clc}
\hline No & Indikator yang diamati & Nilai \\
\hline 1 & Pendahuluan & 78 \\
2 & Kegiatan Inti & 78,1 \\
3 & Penutup & 77 \\
\hline & Nilai Rata-Rata & 77,5 \\
\hline
\end{tabular}

Berdasarkan tabel 2, rata-rata hasil observasi pembelajaran guru masih belum optimal, karena masih terdapat kelemahankelemahan yaitu: 1) diawal pertemuan guru belum menyampaikan tujuan pembelajaran; 2) tidak berperan sebagai fasilitator; 3) pengendalian guru terhadap PJJ masih kurang sehingga partisipasi siswa kurang aktif dalam mengikuti PJJ; dan 4) keaktifan siswa kurang dalam berinteraksi dengan siswa yang lain.

Berdasarkan hasil observasi pembelajaran diatas disarankan agar guru 1) menyampaikan tujuan pembelajaran diawal pertemuan kepada siswa; 2) guru berperan sebagai fasilitator; 3) agar siswa aktif mengikuti proses pembelajaran pengendalian siswa dalam PJJ selalu dilaksanakan; 4) guru memberikan dorongan dan semangat kepada siswa agar saling berinteraksi sesama siswa yang lain.

Hasil pengamatan observer mengacu pada lembar observasi keterlaksanaan Bimtek In-On-In dan catatan lapangan yang menunjukan bahwa kepala sekolah dan narasumber telah melaksanakan tahapan-tahapan pembelajaran sesuai langkah-langkah yang terdapat dalam rencana pelaksananan Bimtek.

Pengamatan observer melalui zoom meeting pada peserta Bimtek, dipertemuan ini guru antusias dan ada kemauan dalam mengikuti Bimtek daring, keterlibatan dalam tanya jawab di zoom mulai aktif, mulai terbiasa dengan zoom meeting dan diskusi berjalan lancar. Pada kegiatan On yang berlangsung dua hari, percakapan guru berlangsung cukup baik. Menyelesaikan RPP dan melakukan telaah silang mulai lancar. Kepala sekolah bersama narasumber memberikan dorongan pada guru untuk mempresentasikan mempresentasikan RPP.

Tabel 3. Hasil Telaah RPP Siklus II

\begin{tabular}{lcc}
\hline \multirow{2}{*}{ No Nama } & \multicolumn{2}{c}{ Siklus 1 } \\
\cline { 2 - 3 } & Nilai & Kategori \\
\hline 1. Identitas dan kelengkapan & 94.12 & Amat \\
komponen & & Baik \\
2. Tujuan pembelajaran & 84.55 & Baik \\
3. Kegiatan pembelajaran & 86.47 & Baik \\
4. Penilaian pembelajaran & 81.61 & Baik \\
5. Lampiran & 83.1 & Baik \\
\hline$\quad$ Rerata & 84.98 & Baik \\
\hline
\end{tabular}

Tabel 3 menunjukkan hasil telaah RPP dari 17 guru pada siklus II yang sudah memenuhi efektif, efisien, dan berorientasi pada siswa. Catatan yang diberikan oleh 17 (tujuh belas) penelaah terhadap 17 (tujuh belas) RPP hampir semua senada bahwa RPP sudah baik dan layak dimplementasikan dalam pembelajaran. Dari empat belas indikator RPP terdapat satu indikator yaitu identitas RPP mencapai Amat Baik. Dua belas indikator menunjukkan capaian Baik, namun masih ada indikator mencapai kriteria Cukup yaitu pada indikator penyusunan materi esensial.

Berdasarkan indikator kebehasilan penelitian tindakan sekolah rata-rata pada Siklus 2 ini sudah melampaui nilai 81. Dengan demikian dapat disimpulkan penelitian ini berhasil. Adapun satu indikator yaitu penyusunan materi esensial belum mencapai 81, oleh karenanya sebagai tindak lanjut akan direncanakan workshop tentang penyusunan materi esensial pada awal tahun ajaran baru serta bimbingan 
berkelanjutan oleh pengawas sekolah, kepala sekolah, dan teman sejawat.

Oberservasi pembelajaran dilakukan guru dan kepala sekolah terhadap guru yang ditunjuk untuk diobservasi dalam guru melakukan pembelajaran.

Tabel 4. Rata-rata Hasil Observasi pembelajaran Siklus II

\begin{tabular}{clc}
\hline No & Indikator yang diamati & Nilai \\
\hline 1 & Pendahuluan & 85,5 \\
2 & Kegiatan Inti & 88,8 \\
3 & Penutup & 92,5 \\
\hline & Nilai Rata-Rata & 88,9 \\
\hline
\end{tabular}

Hasil analisis data observasi pembelajaran siklus 2 pada tabel 4 di atas menunjukkan ratarata hasil observasi sejumlah 4 guru pada siklus 2 telah mengalami kenaikan signifikan dengan rata-rata 88,9 atau kategori Baik. Hasil ini merepresesntasikan kompetensi guru dalam melaksanakan proses pembelajaran telah optimal sesuai yang diharapkan. Catatan yang diberikan oleh 11 (sebelas) observer terhadap 4 (empat) guru model hampir semua senada bahwa pembelajaran sudah baik dan layak dimplementasikan dalam pembelajaran berikutnya. Dari tiga belas indikator observasi pembelajaran yang diamati terdapat 7 (tujuh) indikator Amat Baik. 6 (enam) indikator menunjukkan capaian Baik. Berdasarkan indikator keberhasilan penelitian tindakan sekolah rata-rata pada siklus 2 ini sudah melampaui nilai 81. Dengan demikian dapat disimpulkan penelitian ini berhasil.

Hasil bimtek In-On-In secara daring yang dilaksanakan sebanyak 2 (dua) siklus menunjukkan terjadi peningkatan kemampuani guru dalam menyusun RPP PJJ KKO yang dapat dilihat pada Tabel 5 dan Tabel 6 .

Tabel 5. Hasil Telaah RPP Siklus I dan Siklus II

\begin{tabular}{llccccc}
\hline \multirow{2}{*}{ No Nama } & \multicolumn{2}{c}{ Siklus 1 } & \multicolumn{2}{c}{ Siklus 2 } & Peningkatan \\
\cline { 3 - 6 } & & Nilai & Kategori & Nilai & Kategori & \\
\hline 1. & Identitas dan kelengkapan komponen & 88.24 & Baik & 94.12 & Amat Baik & 5.88 \\
2. & Tujuan pembelajaran & 76.47 & Cukup & 84.55 & Baik & 8.08 \\
3. & Kegiatan pembelajaran & 79.99 & Cukup & 86.47 & Baik & 6.48 \\
4. & Penilaian pembelajaran & 75.73 & Cukup & 81.61 & Baik & 5.88 \\
5. & Lampiran & 79.04 & Cukup & 83.1 & Baik & 4.06 \\
\hline & Rerata & 79.2 & Cukup & 84.98 & Baik & 6.08 \\
\hline
\end{tabular}

Tabel 5 menunjukkan bahwa adanya peningkatan kompetensi guru KKO dalam menyusun RPP JJ. Hasil rata-rata siklus 1 mencapai 79,20 naik menjadi 84,98; Dlam Identitas dan kelengkapan komponen pada siklus 1 dan siklus 2 ada peningkatan kategori dari baik menjadi amat baik. Sedangkan untuk tujuan pembelajaran, kegiatan pembelajaran, penilaian pembelajaran, dan lampiran pada siklus 1 dan siklus 2 ada peningkatan kategori dari cukup menjadi baik. Sehingga dari siklus 1 dan siklus 2 ada peningkatan rerata dari kategori cukup menjadi baik.
Hasil bimtek In-On-In secara daring yang dilaksanakan sebanyak 2 (dua) siklus menunjukkan terjadinya peningkatan kompetensi guru KKO dalam menyusun RPP PJJ.

Dapat disimpulkan bahwa berdasarkan hasil analisis data dan pembahasan Bimtek In-On-In secara daring dapat memberikan bantuan pada guru KKO dalam meningkatkan kemampuan menyusun RPP PJJ yang ditandai dengan peningkatan siklus 1 ke siklus 2 sebesar 6.08

Tabel 6. Hasil Observasi Pembelajaran Siklus I dan Siklus II

\begin{tabular}{|c|c|c|c|c|c|c|}
\hline \multirow{2}{*}{ No } & \multirow{2}{*}{ Nama } & \multicolumn{2}{|c|}{ Siklus 1} & \multicolumn{2}{|c|}{ Siklus 2} & \multirow[t]{2}{*}{ Peningkatan } \\
\hline & & Nilai & Kategori & Nilai & Kategori & \\
\hline & & 78.00 & Cukup & 85.5 & Baik & 7.5 \\
\hline & & 78.11 & Cukup & 88.78 & Baik & 10.67 \\
\hline & & 77.00 & Cukup & 92.5 & Amat Baik & 15.5 \\
\hline & & 77.70 & Cukup & 88.93 & Baik & 11.23 \\
\hline
\end{tabular}


Tabel 6 menunjukkan peningkatan observasi guru KKO dalam menyusun RPP JJ. Hasil ratarata siklus 1 mencapai 77,70 naik menjadi 88,93. Kegiatan pembelajaran yang terdiri dari: pendahuluan dan kegiatan inti pada siklus 1 dan siklus 2 terdapat peningkatan kategori cukup menjadi amat baik. Sedangkan untuk kegiatan penutup pembelajaran pada siklus 1 dan siklus 2 terdapat peningkatan kategori dari cukup menjadi amat baik. Sehingga dari siklus 1 dan siklus 2 terdapat peningkatan rerata dari kategori cukup menjadi baik. Hasil bimtek In-On-In secara daring yang dilaksanakan sebanyak 2 (dua) siklus menunjukkan terjadinya peningkatan kompetensi guru KKO dalam melaksanakan pembelajaran. Dapat disimpulkan bahwa berdasarkan hasil analisis data dan pembahahasan, Bimtek In-On-In secara daring dapat memberikan bantuan pada guru KKO dalam meningkatkan kemampuan kegiatan pembelajaran yang ditandai dengan peningkatan siklus 1 ke siklus 2 sebesar 11,23.

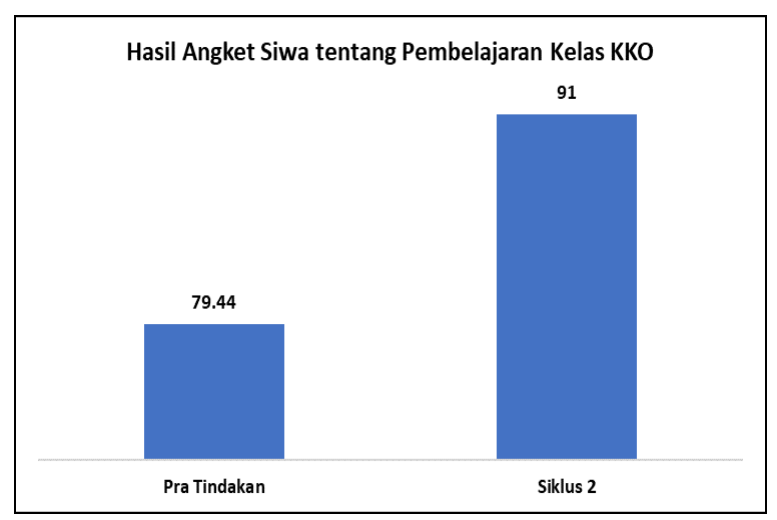

Gambar 1. Diagram Hasil Angket Siswa tentang Pembelajaran

Untuk meyakinkan keberhasilan tindakan dalam penyusunan RPP PJJ guru KKO, peneliti melakukan triangulasi data dengan melihat hasil angket siswa. Berdasarkan Gambar 1 dapat dilihat bahwa hasil peningkatan kompetensi penyusunan RPP sejalan dengan kenaikan kualitas pembelajaran yang dirasakan oleh siswa.

Berdasarkan penelitian Kepler Debataraja dengan judul "Upaya Meningkatkan Kompetensi Guru Dalam Menyusun Rencana Pelaksanaan Pembelajaran Melalui Bimbingan Berkelanjutan di SMP Negeri 1 Siantar Narumonda Kabupaten Toba Samosir Tahun 2018”. Hasil Penelitian Tindakan Sekolah disimpulkan dengan bimbingan berkelajutan motivasi guru meningkat dalam menyusun RPP. Guru lebih serius dalam menyusun RPP. Hal ini dibuktikan dari hasil pengamatan. Pada siklus1 nilai rerata komponen RPP 69\% dan siklus 2 naik 83\%. Jadi terdapat peningkatan $14 \%$
Dari semua indikator, teramati pada pertemuan pertama siklus 1 sebagian guru masih ada yang belum aktif dan sering tidak memunculkan video. Namun pada Siklus 2, berkat komunikasi narasumber yang selalu mendorong dan memotivasi serta memberikan apresiasi maka pertemuan kedua Siklus 1 menjadi lebih baik. Selanjutnya pada siklus 2, teramtai guru memperhatikan pembimbingan, mengajukan pertanyaan kepada narasumber atau sesama guru, menjawab pertanyaan dari narasumber atau guru lain, bekerja sama dengan guru lain untuk menyusun RPP, serta senang mengikuti pembimbingan. Dengan sikap senang maka guru paham, mau menyusun RPP, dan mau mengomunikasikan permasalahan.

Dari pembahasan diatas maka penelilitian ini berhasil terbukti dengan tercapainya indikator keberhasilan. Hasil penelitian ini sejalan dengan penemuan Bimo Walgito (Nurhatun 2019:77) mengatakan bimbingan merupakan bantuan yang diberikan kepada individu atau sekumpulan individu dalam mengatasi kesulitan-kesulitan hidupnya, agar individu dapat mencapai kesejahteraan dalam kehidupannya. Oleh karena itu peneliti menyimpulkan bahwa Bimtek In-OnIn secara daring dapat memberikan bantuan pada guru KKO dalam meningkatkan kompetensi menyusun RPP PJJ sehingga berdampak pula pada peningkatan kualitas pembelajaran.

\section{Simpulan dan Saran}

Melalui kegiatan Bimtek In-On-In secara daring dapat memberikan bantuan pada guru KKO dalam meningkatkan kemampuan menyusun RPP PJJ yang berdampak pada peningkatan kualitas pembelajaran. Hasil kegiatan Bimtek penyusunan RPP PJJ daring dapat meningkatkan kemampuan guru KKO dalam menyusun RPP JJ. Hasil rata-rata Siklus 1 mencapai 79,20 naik menjadi 84,98. Hasil penyusunan RPP PPJ ditriangulasikan dengan hasil observasi pembelajaran dan hasil angket siswa. Dari triangulasi data ini dapat disimpulkan bahwa hasil peningkatan kompetensi penyusunan RPP sejalan dengan kenaikan kualitas pembelajaran yang dirasakan oleh siswa. Perbandingan hasil rata-rata angket siswa pratindakan mencapai 77,44 kategori cukup, dan setelah siklus 2 mencapai 91 kategori amat baik.

Pelaksanaan Bimtek dilakukan secara In-OnIn mulai 10 Pebruari sd. 17 Maret 2021 terbukti berdampak positif terhadap kompetensi penyusunan RPP. Bimtek dilakukan dengan mengajak guru melakukan refleksi tentang pembelajaran yang selama ini dilakukan, selanjutnya diberi pemahaman tentang gaya 
belajar siswa KKO. Alhasil setelah memahami gaya belajar siswa KKO, guru mencoba menyusun RPP PJJ bagi KKO dengan efektif, efiesian, dan berorientasi pada siswa.

Kegiatan Bimtek In-On-In sangat baik untuk memperbaiki kompetensi dan mengembangkan keprofesionalan guru, guru mampu menganalisis kekurangan dan menyimpulkan hal yang perlu diperbaiki jika diberikan pengalaman secara langsung. Keberhasilan Bimtek didukung oleh kerjasama dan komunikais yang baik antara Kepala Sekolah, Pengawas, dan Guru.

\section{Daftar Pustaka}

, (2005). Peraturan Pemerintah No 19 tentang Standar Nasional Pendidikan. Jakarta: Depdiknas.

, (2007). Peraturan Menteri Pendidikan Dan Kebudayaan Nomor 16 tentang Standar Kualifikasi Akademik dan Kompetensi Guru. Jakarta: Kemendikbud. , (2016). Peraturan Menteri Pendidikan Dan Kebudayaan Nomor 22 tentang Standar Proses. Jakara: Kemendikbud

, (2019). Edaran Menteri No 4 tentang Penyederhaan Rencana Pelaksanaan Pembelajaran. Jakarta: Kemendikbud.

Kemmis, S., McTaggart, R., \& Nixon, R. (2013). The action research planner: Doing critical participatory action research. London: Springer Science \& Business Media.

Setiana. D. S. (2018). Meningkatkan Kemampuan Menyusun RPP Dengan Pendekatan Saintifik Mahasiswa Pendidikan Matematika Universitas Sarjanawiyata
Tamansiswa Yogyakarta. Prosiding Seminar Nasional MIPA, Magelang.

Tan, S.S. \& Indrasti, R. (2018). Efektifitas Bimbingan Teknis Dalam Pengembangan Perbenihan Holtikultura Di Jawa Barat. Jurnal Pengkajian dan Pengembangan Pertanian, 21 (3), 245-257.

Pratiwi Eka Wahyu. (2020). Strategi Komunikasi Interpersonal Guru Dalam Pelaksanaan Pembelajaran Jarak Jauh Di Sekolah Dasar Klaten Jawa Tengah. Jurnal Psikologi Pendidikan Dan Pengembangan SDM. 9(2).

Sa'bani Faizuz. (2017). Peningkatan Kompetensi Guru Dalam Menyusun RPP Melalui Kegiatan Pelatihan Pada MTs Muhammadiyah Wonosari. Jurnal Pendidikan Madrasah, 2(1) 527-4287.

Setiana. D. S. (2018). Meningkatkan Kemampuan Menyusun RPP Dengan Pendekatan Saintifik Mahasiswa Pendidikan Matematika Universitas Sarjanawiyata Tamansiswa Yogyakarta. Prosiding Seminar Nasional MIPA, Magelang.

Sudarmadi. (2017). Penerapan Mentoring Pola In-On-In Untuk Meningkatkan Kinerja GuruGuru IPA SMA Binaan Dalam Menyusun Perencanaan Penilaian Pembelajaran Di Kulon Progo. Jurnal Ilmiah Guru "COPE", 02. Sunarsi Denok dan Yuangga Kharisma Danang. (2020). Pengembangan Media Dan Strategi Pembelajaran Untuk Mengatasi Permasalahan Pembelajaran Jarak Jauh Di Pandemi COVID- 19. Guru Kita. 4(3), 25491288. 